\title{
Use of new technologies to detect and understand HIV drug resistance
}

Michael J Kozal

From $16^{\text {th }}$ International Symposium on HIV and Emerging Infectious Diseases

Marseille, France. 24-26 March 2010

New sensitive genotyping technologies can detect low level drug resistant variants that are often missed by standard methods. New technologies have the potential to help the field investigate important viral population characteristics which may impact antiretroviral treatment responses. Specific viral factors such as the number of viral variants with drug resistance mutations in the circulating quasispecies (resistance mutational load), genetic linkage (mutations within the same viral genome), and specific mutation patterns may all impact treatment response. The detection level for particular resistance mutations and the relative mutational loads required to predict virologic failure for different regimens requires better definition. The ability to identify mutation linkage may improve the prediction of virologic failure. It should be emphasized that not all low level resistant variants lead to virologic failure as other active agents in a regimen (with different genetic barriers) may suppress the resistant variant. New sensitive genotyping methods have limitations due to both the inability to extract a fully representative sample of all viral variants present in blood and by the intrinsic error rates of the enzymatic and detection processes employed. These limitations can lead to discordant results between different sensitive technologies. The impact of low level resistant variants on treatment response is likely a multifactorial process with mutation load, linkage, and the genetic barrier of the regimen all contributing. The development of new genotypic resistance technology will allow the field to examine how these factors interact and impact therapy. This paper will describe some of the new sensitive technologies to detect genotypic drug resistance and the

Yale University School of Medicine and VA CT Healthcare System New Haven, CT, USA

BioMed Central @ 2010 Kozal; licensee BioMed Central Ltd. important questions that need to be addressed to help improve their clinical utility.

Published: 11 May 2010

doi:10.1186/1742-4690-7-S1-119

Cite this article as: Kozal: Use of new technologies to detect and understand HIV drug resistance. Retrovirology 2010 7(Suppl 1):119.

Submit your next manuscript to BioMed Central and take full advantage of:

- Convenient online submission

- Thorough peer review

- No space constraints or color figure charges

- Immediate publication on acceptance

- Inclusion in PubIMed, CAS, Scopus and Google Scholar

- Research which is freely available for redistribution

Submit your manuscript at www.biomedcentral.com/submit 